\title{
EDITORIAL
}

\section{Elenor Kunz}

Editor

As pesquisas da área de Educação Física e Esportes no Brasil, em grande parte, ainda se reduzem, ao que poderíamos chamar de "experiências iniciais de pesquisadores", ou seja, investigações com pouca ou nenhuma visão da totalidade da área, pesquisas de/com fragmentos da área. Isso se deve possivelmente porque a área não apresenta ainda um campo definido de pesquisa científica e porque as investigações nos programas de Pós-Graduação onde a maioria das pesquisas acontecem se configuram em pesquisas apressadas, para integrar a dissertação ou tese ou para publicar porque o "sistema" exige.

Neste sentido as pesquisas pedagógicas da área encontram um dilema muito grande, ou seja, partir para a construção de fundamentos científicos com teorias das Ciências Humanas cada vez mais complexas e extensas ou avançar nos conhecimentos empíricos e de campo da área para explicar e compreender melhor o que ainda não se tem conhecimento suficiente. Ambas investidas são irrealizáveis em curto prazo, logo tem-se a sensação, como acima dito, de "experiências inicias" em pesquisa.

Já as pesquisas no campo da biodinâmica do movimento como preferem chamar atualmente as que se interessam pelas ciências da natureza encontram problemas com duplicação de temáticas de investigação e com as instâncias da aplicabilidade de seus conhecimentos científicos em realidades distintas.

Como editor de revista e profissional da área em apreço, não posso me atrever a julgar em detalhes essas problemáticas levantadas e muito menos afirmar que com isso então deveríamos pesquisar menos e publicar menos com a esperança de melhorar a qualidade e os resultados, em termos de relevância social, das pesquisas, NÃO ao contrário creio que para alcançar isso devemos continuar pesquisando mais e publicando mais para que a própria comunidade científica juntamente com os profissionais que se nutrem (ou deveriam se nutrir) destas pesquisas possam avaliar melhor e fornecer indicadores sócio científicos e profissionais para avançar.

Neste primeiro numero de 2017 da revista Kinesis estamos publicando artigos que abordam assuntos pedagógicos de metodologias de ensino, currículo, saúde, aprendizagens entre outros e assuntos da biodinâmica com temas do treino, da competição e da fisiologia.

Assim, atendemos um bom número de trabalhos que nos foram enviados, não apenas com os que estamos publicando mas com um grande número de artigos que pelo crivo de nossos avaliadores foram devolvidos para correção. Mesmo assim, estamos esperando novos artigos para nossos próximos números deste ano, agosto e dezembro, porque passamos a publicar quadrimestralmente. 